Egyptian Journal of Aquatic Biology \& Fisheries

Zoology Department, Faculty of Science,

Ain Shams University, Cairo, Egypt.

ISSN $1110-6131$

Vol. 24(2): 265 - 290 (2020)

www.ejabf.journals.ekb.eg

\title{
Evaluation of Potential Health Risk, Heavy Metal Pollution Indices and Water Quality of Edku Lagoon- Egypt
}

\author{
Said A. Shetaia ${ }^{1} *$, Atef M. Abu Khatita ${ }^{1}$, Nabil A. Abdelhafez ${ }^{1}$, \\ Ibrahim M. Shaker², Sameh B. El Kafrawy ${ }^{3}$
}

1. Geology Department, Al-Azhar University, Cairo, Egypt

2. Limnology Department, Central Laboratory for Aquaculture Research (CLAR), Abassa, Egypt

3. Department of Marine Sciences, National Authority for Remote Sensing and Space Sciences

(NARSS), Egypt

*Corresponding Author: said_abdelhady@azhar.edu.eg

ARTICLE INFO

\section{Article History:}

Received: March 11, 2020

Accepted: March 30, 2020

Online: April 2020

Keywords:

Edku lagoon,

Heavy metals,

Pollution indices,

Water quality index,

Health risk assessment

\section{ABSTRACT}

Edku lagoon is one of the important aquaculture sectors in the Nile Delta of Egypt. Recently, the lagoon has become a sink of discharge wastewater from different anthropogenic sources. The present work aims to study physicochemical parameters, level of nutrients and heavy metal concentrations in water of the lagoon to assess the water quality and identify the potential pollution source(s). Water quality index (WQI), eutrophication index and multiple heavy metal pollution indices (HPI, HEI, PI and $\mathrm{C}_{\mathrm{d}}$ ) in addition to evaluation of human health risk $\left(\mathrm{HQ}_{\text {dermal }}\right)$ model were applied. The obtained data revealed that physicochemical parameter varied between $7.62-8.90$ for $\mathrm{pH}, 1.2-12.2 \mathrm{~g} / \mathrm{l}$ for salinity, $3.5-12.5 \mathrm{mg} / \mathrm{l}$ for dissolved oxygen, $1.3-1.9 \mathrm{mg} / \mathrm{l}$ for ammonia, $0.065-0.191 \mathrm{mg} / \mathrm{l}$ for nitrite, 0.217 $0.915 \mathrm{mg} / \mathrm{l}$ nitrate, $0.198-0.527 \mathrm{mg} / \mathrm{l}$ for orthophosphate, and 51.32 $102.7 \mu \mathrm{g} / 1$ for chlorophyll- $a$. The average concentrations of heavy metals were $0.439,0.322,0.290,0.328,0.059,0.040,0.00005 \mathrm{ppm}$ for $\mathrm{Fe}$, $\mathrm{Mn}, \mathrm{Zn}, \mathrm{Cu}, \mathrm{Pb}, \mathrm{Cd}$ and $\mathrm{Hg}$, respectively. Based on WQI, the lagoon was classified as bad water, while EI result varied between eutrophic to mesotrophic. The pollution indices revealed to lagoon water is highly contaminated based on HPI, HEI and $\mathrm{C}_{\mathrm{d}}$ and varied between slightly affected to seriously affected by heavy metals according to PI. Human health risk showed that, $\mathrm{HQ}_{\mathrm{dermal}}$ for all metals except $\mathrm{Cd}$ lower than the unity.

\section{INTRODUCTION}

Contamination of aquatic environment by heavy metals (HMs) is a critical concern due to their potential toxicity and accumulation in aquatic habitats (Jordan et al., 2014; Tscheikner-Gratl et al., 2019). Under certain environmental conditions, HMs could accumulate to a toxic concentration level and then cause significant ecological impacts and problems for human health (Jaishankar et al., 2014; Wongsasuluk et al., 
2014). HMs have a particular significance in ecotoxicology due to their long persistence, bioaccumulation and biomagnification in the food chain (Yin et al., 2019). They are nondegradable and continuously increasing in water bodies (Salomons and Forstner, 2012) and consequently bioaccumulate along the food chain, causing toxic effects at points far from the source of pollution (Strom, 2008; Ebrahimpour and Mushrifah, 2010; Weber et al., 2013). Egyptian coastal lagoons considered an important source of aquaculture sectors. These lagoons occupy about $13 \%$ of worldwide coastal areas and $25 \%$ of total wetlands of the Mediterranean (Saad, 2003). The northern wetlands represented by the main five lagoons (Mariut, Edku, Burullus, Manzala and Bardawil) are distributed along the northern shoreline of Egypt, from west to east, respectively.

Edku lagoon is the third largest wetland area in the Nile Delta. It lies just west of Rosetta branch of River Nile and currently covers an area of about $62.5 \mathrm{~km}^{2}$, which represents less than the half of its original size $\left(120\right.$ to $\left.130 \mathrm{~km}^{2}\right)$ (Zaghloul and Hussein, 2000; Okbah and El-Gohary, 2002). Edku lagoon represent about $15 \%$ of the total commercial fishing areas in Egypt (Abdel-Hamid, 2017). Intrusion of seawater to the lagoon is through Boughaz El-Maadia, where the lagoon connected with Mediterranean Sea. There are two main drains facilitate discharging the wastewater to the eastern side of the lagoon; the Bersik and Kom Belag (Okbah and El-Gohary, 2002; Shakweer, 2006). The Kom Belag drain releases only about 1/6 of the Bersik Drain's effluent. Together they discharge about $2 \times 10^{9} \mathrm{~m}^{3} \mathrm{yr}^{-1}$ to the eastern region, where this side of the lagoon is heavily vegetated and less than $1 \mathrm{~m}$ depth (Al Sayes et al., 2007). These drains responsible for increasing the contamination in the lagoon. Increasing contamination associated with increasing levels of heavy metals and nutrients, which have caused eutrophication and adversely affected the fishery (Soliman et al., 2006; Chen et al., 2010).

Therefore, the present study aims to investigate the physico-chemical parameters and heavy metal concentrations to asses water quality index (WQI) in addition to eutrophication Index (E.I.) of Edku lagoon. Moreover, evaluate pollution indices such as Pollution index (PI), heavy metal pollution index (HPI), heavy metal evaluation index (HEI), contamination index $\left(\mathrm{C}_{\mathrm{d}}\right)$, and its potential health risk assessment $\left(\mathrm{HQ}_{\mathrm{dermal}}\right)$.

\section{MATERIALS AND METHODS}

\section{Study Area}

Edku lagoon is one of the northern coastal lagoons in Egypt, located at the western part of the Nile Delta. It is situated just about $30 \mathrm{~km}$ east of Alexandria between longitude $30^{\circ} 8^{\prime} 30^{\prime \prime}$ and $30^{\circ} 23^{\prime} 0.0^{\prime \prime} \mathrm{E}$ and latitude $31^{\circ} 10^{\prime} 30^{\prime \prime}$ and $31^{\circ} \mathrm{N}$. The lagoon is connected to the Mediterranean Sea through a narrow channel (Boughaz El-Maadia). The lagoon has an area (total) about $62.5 \mathrm{~km}^{2}$, while open water is about $22 \mathrm{~km}^{2}$ (35\% of the total surface area) and the remaining area $\left(42.7 \mathrm{~km}^{2}\right)$ covered by aquatic vegetation, or islands and islets (Moufaddal $\boldsymbol{e t}$ al., 2008; Khalil and Rifaat, 2013). The lagoon depth 
fluctuates between 60 and $150 \mathrm{~cm}$ with an average of about one meter (Saad, 2003). Two main drains discharge their water into the lagoon. The first drain namely Kom Belag receives its water from three subdrains; Bosily, Edku and El-Khairy where they are connected at about $3 \mathrm{~km}$ to the east of the lagoon. The drainage water of kom Belag drain is discharged at the eastern part of the lagoon. The second main drain connected to Edku lagoon is Bersik drain which outlets its water at the southern central part of this lagoon.

\section{Sampling And Analysis}

Seven water samples (at $30 \mathrm{~cm}$ depth) were collected from Edku lagoon (Fig. 1) using Kemmerer water sampler during 2018. Location of selected sites (Table 1) were determined using Geographic Positioning System (GPS). During sampling, temperature, $\mathrm{pH}$, salinity and dissolved oxygen were measured using multi parameter hand-held meter (Model SensoDirect 150). Water samples were kept in acid cleaned stoppered plastic bottles for later examination and acidified with $\mathrm{HNO}_{3}(1 \mathrm{ml})$, then kept refrigerated and transferred in an ice box to the laboratory. Total ammonia concentration was measured by Hach comparison. Nitrite, $\mathrm{NO}_{2}-\mathrm{N}$ (mg/l) was measured by Diazotizing method at 543 $\mathrm{nm}$. Nitrate, $\mathrm{NO}_{3}-\mathrm{N}(\mathrm{mg} / \mathrm{l})$ was determined by Phenoldisulphonic acid method at $410 \mathrm{~nm}$. Ortho-phosphorus $(\mathrm{mg} / \mathrm{l})$ and chlorophyll- $a(\mu \mathrm{g} / \mathrm{l})$ concentration were determined photometrically using Spectrophotometer Thermo Electron Corporation (model Nicolet Evolution 100). Heavy metals concentrations (ppm) were determined by atomic absorption spectrophotometer (Thermo Electron Corporation S Series AA Spectrometer). All parameters were determined according to APHA (2000).

Table 1: Location of Sampling stations.

\begin{tabular}{ccc}
\hline Station & Latitude & Longitude \\
\hline $\mathbf{1}$ & $31^{\circ} 16^{\prime} 11.86^{\prime \prime} \mathrm{N}$ & $30^{\circ} 13^{\prime} 52.43^{\prime \prime} \mathrm{E}$ \\
$\mathbf{2}$ & $31^{\circ} 16^{\prime} 4.57^{\prime \prime} \mathrm{N}$ & $30^{\circ} 14^{\prime} 29.71^{\prime \prime} \mathrm{E}$ \\
$\mathbf{3}$ & $31^{\circ} 15^{\prime} 15.54^{\prime \prime} \mathrm{N}$ & $30^{\circ} 14^{\prime} 7.77^{\prime \prime} \mathrm{E}$ \\
$\mathbf{4}$ & $31^{\circ} 14^{\prime} 24.54^{\prime \prime} \mathrm{N}$ & $30^{\circ} 13^{\prime} 10.97^{\prime \prime} \mathrm{E}$ \\
$\mathbf{5}$ & $31^{\circ} 15^{\prime} 11.84^{\prime \prime} \mathrm{N}$ & $30^{\circ} 12^{\prime} 23.79^{\prime \prime} \mathrm{E}$ \\
$\mathbf{6}$ & $31^{\circ} 16^{\prime} 16.48^{\prime \prime} \mathrm{N}$ & $30^{\circ} 18^{\prime} 40.74^{\prime \prime} \mathrm{E}$ \\
$\mathbf{7}$ & $31^{\circ} 15^{\prime} 51.79^{\prime \prime} \mathrm{N}$ & $30^{\circ} 10^{\prime} 40.95^{\prime \prime} \mathrm{E}$ \\
\hline
\end{tabular}

\section{Water Quality Index (WQI)}

The WQI is considered to be a tool for simplifying the reporting of water quality data. WQI numerically summarizes the data from multiple water quality parameters into a single value. The single value can be used to compare data from several sites. WQI calculated according to Yidana and Yidana (2010) and Alobaidy et al. (2010) as follow:

Each of the studied parameters has been assigned a weight $(A W i)$ ranging from 1 to 5 depending on the significant. In this study, the parameters that have been considered are; $\mathrm{pH}, \mathrm{DO}, \mathrm{NO}_{3}, \mathrm{NO}_{2}, \mathrm{Cd}, \mathrm{Cu}, \mathrm{Fe}, \mathrm{Mn}, \mathrm{Pb}, \mathrm{Zn}$ and $\mathrm{Hg}$ according to (Alobaidy et al., 2010; Ravikumar et al., 2013). 
The relative weight $(R W)$ was calculated by using the following equation:

$$
R W=\frac{A W_{i}}{\sum_{i=1}^{n} A W_{i}}
$$

Where, $R W=$ the relative weight, $A W=$ the assigned weight of each parameter, $\mathrm{n}=$ the number of parameters (Table 2).

A quality rating scale $(Q i)$ for all the parameter was assigned by dividing its concentration in each water sample by its respective standard recommended by CCME (2007), the result was then multiplied by 100 .

$$
Q i=\left[\frac{C_{i}}{S_{i}}\right] \times 100
$$

Where, $Q i=$ the quality rating, $C_{i}=$ value of the water quality parameter obtained from the laboratory analysis, $S_{i}=$ value of the water quality parameter obtained from recommended CCME (2007), Computing the WQI, the sub-indices $\left(S I_{i}\right)$ were first calculated for each parameter, and then used to compute the $W Q I$ as in the following equations:

$$
S I_{i}=R W \times Q_{i}, W Q I=\sum_{i=1}^{n} S I_{i}
$$

The computed WQI values could be classified as $<50=$ Excellent; 50-100 = Good; 100$200=$ Poor; $200-300=$ Very poor; $>300=$ Bad water (unsuitable for aquatic life) .

Table 2: Assigned weight $(A W)$ and relative weight $(R W)$ of the water quality parameters.

\begin{tabular}{cccc}
\hline Parameters & $\begin{array}{c}\text { CCME } \\
(\mathbf{2 0 0 7}) \\
\text { standard }\end{array}$ & $\begin{array}{c}\text { Assigned } \\
\text { weight } \\
(\boldsymbol{A} W)\end{array}$ & $\begin{array}{c}\text { Relative } \\
\text { weight }(\boldsymbol{R} W)\end{array}$ \\
\hline Cd (mg/l) & 0.001 & 3 & $\mathbf{0 . 0 9 3}$ \\
Cu (mg/l) & 0.004 & 2 & $\mathbf{0 . 0 6 2}$ \\
Fe (mg/l) & 0.3 & 3 & $\mathbf{0 . 0 9 3}$ \\
Mn $(\mathbf{m g} / \mathbf{l})$ & 0.05 & 3 & $\mathbf{0 . 0 9 3}$ \\
Pb (mg/l) & 0.007 & 5 & $\mathbf{0 . 1 5 5}$ \\
Hg (mg/l) & 0.000016 & 4 & $\mathbf{0 . 1 2 4}$ \\
Zn (mg/l) & 0.05 & 2 & $\mathbf{0 . 0 6 2}$ \\
$\mathbf{p H}$ & $6.5-9$ & 2.1 & $\mathbf{0 . 0 6 5}$ \\
DO (mg/l) & 5.5 & 4 & $\mathbf{0 . 1 2 4}$ \\
NO3 (mg/l) & 2.93 & 2.2 & $\mathbf{0 . 0 6 8}$ \\
NO2 (mg/l) & 0.06 & 2 & $\mathbf{0 . 0 6 2}$ \\
Total & & $\mathbf{3 2 . 3}$ & $\mathbf{1}$ \\
\hline
\end{tabular}

\section{Eutrophication Index (E.I.)}

In this study we assessed the eutrophication status of Edku lagoon using the eutrophication index (E.I.). Primpas et al. (2010) proposed the Eutrophic Index (EI) to assess trophic status based on five-point scales. This index is given by: 


$$
\text { E. I. }=0.279 \mathrm{C}_{\mathrm{po}_{4}}+0.261 \mathrm{C}_{\mathrm{NO}_{\mathrm{g}}}+0.296 \mathrm{C}_{\mathrm{NO}_{\mathrm{g}}}+0.275 \mathrm{C}_{\mathrm{NH}_{\mathrm{g}}}+0.214 \mathrm{C}_{\mathrm{Chl}-\mathrm{a}}
$$

where $\mathrm{C}$ is the concentration of the indicated nutrient or chl-a (Primpas et al., 2010). The calculated E.I. values could be classified as < $0.04=$ Ultra Oligotrophic/High; 0.04-0.38 = Oligotrophic/Good; 0.38-0.85 = Mesotrophic/Moderate; $0.85-1.51=$ Eutrophic/Poor; > $1.51=$ Dystrophic/Bad.

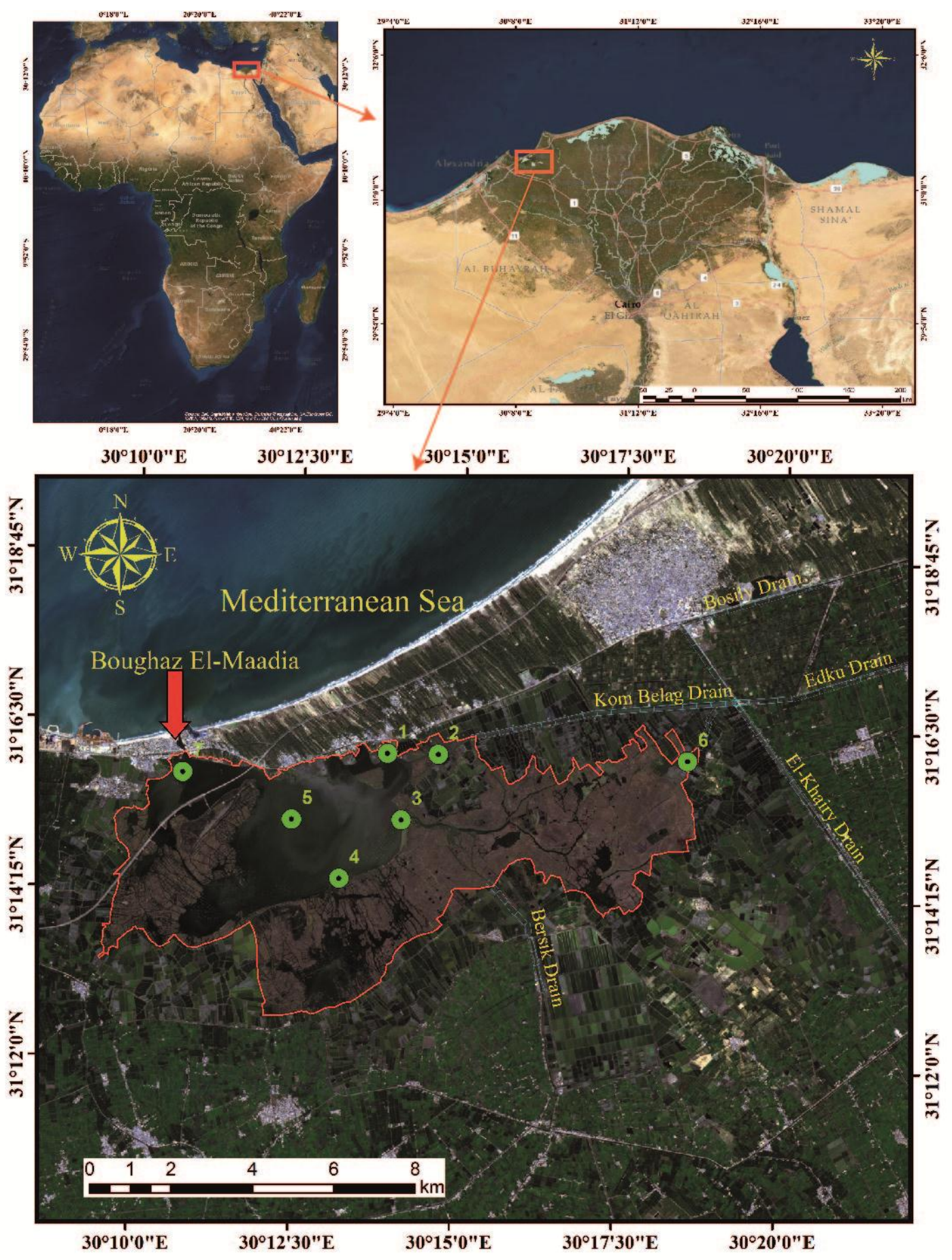

Fig. 1: location map of Edku lagoon showing sampling stations. 


\section{Pollution Assessment Indices}

Several pollution indices were employed to determine the pollution status of heavy metals in Edku lagoon.

\section{Pollution Index (PI)}

Pollution index is based on individual metal calculations and categorized to five classes (Table 3) according to the following equation (Caeiro et al., 2005):

$$
\mathrm{PI}=\frac{\sqrt{\left[\left(\frac{C i}{S i}\right)_{\max }^{2}+\left(\frac{C i}{S i}\right)_{\min }^{2}\right]}}{2}
$$

where $\mathrm{Ci}$ is the concentration of each element, and $\mathrm{Si}$ is the standard values according to CCME (2007).

Table 3: Categories of water pollution index

\begin{tabular}{ccc}
\hline Class & PI value & Class \\
\hline 1 & $<1$ & No effect \\
2 & $1-2$ & Slightly affected \\
3 & $2-3$ & Moderately affected \\
4 & $3-5$ & Strongly affected \\
5 & $>5$ & Seriously affected \\
\hline
\end{tabular}

\section{Heavy Metal Pollution Index (HPI)}

This index gives the combined effect of individual heavy metals on surface water quality (Sheykhi and Moore, 2012). For this index, a rating is given to each heavy metal based on its relative significance and defined as inversely proportional to the recommended standard value for each heavy metal (Reddy, 1995). The HPI model (Mohan et al., 1996) is given by

$$
H P I=\frac{\sum_{i=1}^{n} W_{i} Q_{i}}{\sum_{i=1}^{n} W_{i}}
$$

Where, $\mathrm{W}_{\mathrm{i}}$ is the unit weighting of the ith heavy metal, $\mathrm{Q}_{\mathrm{i}}$ is the sub-index for the ith heavy metal, and $\mathrm{n}$ is the number of heavy metals which equals 6 ( $\mathrm{Fe}, \mathrm{Mn}, \mathrm{Zn}, \mathrm{Cu}, \mathrm{Pb}$ and $\mathrm{Cd}$ ) for this study. The sub-index $\left(\mathrm{Q}_{\mathrm{i}}\right)$ is calculated by:

$$
Q_{i}=\sum_{i=1}^{n} \frac{\left.\llbracket M_{i}-I_{i}\right\rfloor}{s_{i}-I_{i}} \mathbf{1 0 0}
$$

where $\mathrm{M}_{\mathrm{i}}$ is the monitored value of heavy metal of ith parameter, $\mathrm{I}_{\mathrm{i}}$ is the ideal value of the ith parameter and $S_{i}$ is the standard value of the ith parameter. The critical pollution index of HPI value for drinking water as given by Prasad and Bose (2001) is 100. The 
weightage $\left(\mathrm{W}_{\mathrm{i}}\right)$ was taken as the inverse of MAC (MAC adapted from Siegel, 2002), $\mathrm{S}_{\mathrm{i}}$ the WHO standard for drinking water and $\mathrm{I}_{\mathrm{i}}$ the guide value for the chosen element (Edet and Offiong, 2002) (Table 4).

A value of HPI below 100 represents low pollution of heavy metals, while 100 is the threshold value at which harmful health consequences are probable. An HPI value greater than 100 indicates the water is unsuitable for consumption (Kumar et al., 2019).

Table 4: Standard values used for the indices computation.

\begin{tabular}{ccccc}
\hline Parameters & W & S & I & MAC \\
\hline Fe & 0.005 & 0.3 & 0.2 & 0.2 \\
Mn & 0.02 & 0.1 & 0.5 & 0.05 \\
$\mathbf{Z n}$ & 0.0002 & 5 & 3 & 5 \\
$\mathbf{C u}$ & 0.001 & 1 & 2 & 1 \\
$\mathbf{P b}$ & 0.7 & 0.1 & 0.01 & 0.0015 \\
$\mathbf{C d}$ & 0.3 & 0.005 & 0.003 & 0.003
\end{tabular}

$\mathrm{W}$ is weightage (1/M $\overline{\mathrm{AC}}), \mathrm{S}$ is standard permissible in ppm, I is highest permissible in ppm and MAC is maximum admissible concentration

\section{Heavy Metal Evaluation Index (HEI)}

HEI represents the overall surface water quality with respect to heavy metals content, and is calculated by the following equation (Al-Ani et al., 1987; Ameh, 2013):

$$
H E I=\sum_{i=1}^{n} \frac{M_{i}}{M A C_{i}}
$$

where $\mathrm{M}_{\mathrm{i}}$ and $\mathrm{MAC}_{\mathrm{i}}$ are the monitored value and maximum admissible concentration of the ith parameter, respectively. The calculated HEI values could be classified as $<10$ for low, 10 - 20 for moderate and $>20$ for high pollution.

\section{Contamination Index $\left(\mathbf{C}_{\mathbf{d}}\right)$}

The $C_{d}$ is computed separately for each sample of water analyzed, as a sum of the contamination factors of individual components exceeding the upper permissible value (Edet and Offiong, 2002) and determined as:

$$
\begin{gathered}
\boldsymbol{C}_{d}=\sum_{i=1}^{n} C_{f i} \\
\boldsymbol{C}_{f i}=\frac{\boldsymbol{C}_{A i}}{\boldsymbol{C}_{N i}}-1
\end{gathered}
$$

Where, $\mathrm{C}_{\mathrm{fi}}=$ contamination factor for the $\mathrm{i}$-th component, $\mathrm{C}_{\mathrm{Ai}}=$ analytical value for the $\mathrm{i}$ th component, $\mathrm{C}_{\mathrm{Ni}}=$ upper permissible concentration of the $\mathrm{i}$-th component $(\mathrm{N}$ denotes the 'normative value') and $\mathrm{C}_{\mathrm{Ni}}$ is taken as MAC. The computed $\mathrm{C}_{\mathrm{d}}$ values could be classified as: low $\left(\mathrm{C}_{\mathrm{d}}<1\right)$, medium $\left(\mathrm{C}_{\mathrm{d}}=1-3\right)$ and high $\left(\mathrm{C}_{\mathrm{d}}>3\right)$. 


\section{Human health Risk Assessments}

Risk assessment is defined as the method of assessing the possibility of occurrence of any given possible magnitude of adverse health effects over a specified time period and is a function of the hazard and exposure. Meanwhile, the potential exposure of humans to trace metals could be through three main pathways such as direct ingestion, inhalation and dermal absorption through exposed skin (USEPA, 2004; Wu $\boldsymbol{e t}$ al., 2009; Meng et al., 2016). Fishermen population spend more time with contact with lagoon water during fishing. Therefore, the exposure dose for dermal absorption through exposed skin was calculated as the following:

$$
C D_{d}=\frac{C w \times S A \times K p \times E T \times E F \times E D \times C F}{B W \times A T}
$$

where $C D_{d}$ is the dermal absorption, $\mu \mathrm{g} / \mathrm{kg} / \mathrm{day} ; C w$ is the concentration of heavy metal in water, $\mu \mathrm{g} / \mathrm{l} ; S A$ is the exposed skin area, in this study, $17,000 \mathrm{~cm}^{2} ; K p$ is the skin permeability coefficient in water, $\mathrm{cm} / \mathrm{h} ; E T$ is the exposure time during bathing and shower, in this study $0.6 \mathrm{~h} /$ day; $E F$ is the exposure frequency, in this study 350 day/year assuming that the local inhabitants spend 15 days of the year outside the site; $E D$ is the exposure duration, in this study 68 years; $C F$ is the unit conversion factor, $11 / 1000 \mathrm{~cm}^{3}$; $B W$ is the average body weight, in this study $65 \mathrm{~kg} ; A T$ is the averaging time (in days), $E D \times 365$ days, in this study 23,800. These values were obtained from Tripathee $\boldsymbol{e t}$ al . (2016).

The human health risk assessment was computed using Hazard Quotients (HQs) for metals as the following:

$$
H Q s=\frac{C D_{d}}{R f D}
$$

where, RfD is the reference dose for different metals, for Fe: 45, Mn: 0.8, Zn: 60, Cu: 12, $\mathrm{Pb}: 0.42 \mathrm{Hg}$ : 0.0003 and $\mathrm{Cd}: 0.005 \mu \mathrm{g} / \mathrm{kg} /$ day, according to U.S. risk-based assessments (USEPA, 2006).

\section{RESULTS AND DISCUSSION}

\section{Physico-chemical Parameters}

The results of physico-chemical parameters in all stations are tabulated in Table 5 and their spatial distribution are illustrated in Fig. 2.

The $\mathrm{pH}$ of water determines the solubility and biological availability of chemical constituents such as nutrients and heavy metals. It is interdependent with the most water quality constituents, including carbon dioxide, alkalinity and hardness and influence the toxicity of hydrogen sulphide, cyanides and heavy metals, as well as having an indirect effect on ammonia levels; unionized $\mathrm{NH}_{3}$ increases with $\mathrm{pH}$ increasing (Klontz, 1993). $\mathrm{pH}$ values ranged from 7.6 at station 2 to 8.9 at station 6 with an average value of 8.2. Spatially, $\mathrm{pH}$ values increase towards eastern and western parts of Edku lagoon and decrease at the middle part of the lagoon. Decreasing $\mathrm{pH}$ value at the middle part may 
refer to liberation of $\mathrm{CO}_{2}$ and $\mathrm{H}_{2} \mathrm{~S}$ during the decomposition of organic matter as a result of the waste water discharge in addition to the shortness activities of phytoplankton (Khalil, 1990; Ali, 2008). These areas affected by drainage water disposal via Kom Belag and Bersik drains. It worth to mention that $\mathrm{pH}$ values correlate $(\mathrm{r}=0.8)$ with dissolved oxygen. Changes in $\mathrm{pH}$ and $\mathrm{DO}$ are both affected by algal photosynthesis, aquatic respiration, water temperature and oxidative decomposition of organic matter (Scholz, 2006). Moreover, the consumption or production of carbon dioxide is often accompanied by the production or consumption of oxygen (Zang et al., 2011). It is worth mentioning that, the average value of $\mathrm{pH}$ of Edku lagoon (8.2) is close to the average $\mathrm{pH}$ values of Manzala (8.5) (Abu Khatita et al., 2017) and Bardawil (8.4) lagoons (El-Kassas et al., 2016).

Dissolved oxygen refers to the level of free, non-compound oxygen present in water. It is one of the important factors controlling the biota in the aquatic habitat. Oxygen content can be used as an indicator of organic loading, nutrient input and biological activity (El-Enany, 2004; Shakweer, 2005). Fish stop feeding if the level drops to around 3-4 ppm and die if DO falls to $1 \mathrm{ppm}$ (Weiner, 2000). Many fish can killed not by direct toxicity of contaminants, but also due to the deficiency of oxygen through the biodegradation of contaminants (Weiner, 2000). The DO levels ranged from $3.5 \mathrm{mg} / \mathrm{l}$ at station 3 to $12.5 \mathrm{mg} / \mathrm{l}$ at station 5 with an average of $6.7 \mathrm{mg} / \mathrm{l}$. Based on the lateral variation in DO values, the lagoon divided into eastern side which displayed lower DO values and western side which characterized by higher DO values. The areas which have lower DO value are mainly affected by drainages water. The depletion of dissolved oxygen may attribute to nitrification process or decomposition of organic matter and detrital materials that consume dissolved oxygen. Table 7 shows that, DO in Edku lagoon displays reversible relations with nitrite, nitrate, orthophosphate and chlorophyll-a $(\mathrm{r}=-67$, $-0.72,-0.65$ and -0.63 , respectively). These relations confirm depletion of DO duo to increasing nutrients as well as consuming of oxygen during nitrification process. Compared with the other Nile Delta lagoon, the average value $(6.7 \mathrm{mg} / \mathrm{l})$ of dissolved oxygen in Edku lagoon are greater than value $(5 \mathrm{mg} / \mathrm{l})$ of Manzala lagoon (Abu Khatita et al., 2017).

Salinity is an ecological factor of considerable importance, influencing the types of organisms that live in a body of water. Water salinity is classified into; fresh water (< $0.5 \mathrm{~g} / \mathrm{l})$, brackish water $(0.5-30 \mathrm{~g} / \mathrm{l})$, saline water $(30-50 \mathrm{~g} / \mathrm{l})$, and brine water $(>50$ $\mathrm{g} / \mathrm{l})$. El-Enany (2004), mentioned that salinity is one of the most important factors that affect dynamics, composition, distribution and diversity of bottom population in many 
aquatic ecosystems.. Salinity varied significantly from $1.2 \mathrm{~g} / \mathrm{l}$ at station 1 to $12.2 \mathrm{~g} / \mathrm{l}$ at station 7 with average value of $3.4 \mathrm{~g} / \mathrm{l}$. It is increases towards Boughaz El-Maadia and decrease towards drains. The highest values of salinity are observed in the northern part of the lagoon close to Boughaz area where saline water of Mediterranean Sea discharges to the lagoon. On the other hand, the eastern part of Edku lagoon is characterized by low salinity as a result of the drains that supply the lagoons with about $2 \times 10^{9} \mathrm{~m}^{3} \mathrm{yr}^{-1}$ of freshwater (Oczkowski and Nixon, 2010). Also, expansion of fish farming activities contributed for increasing the volume of drainage water (Shakweer, 2006). Comparatively, the average value of salinity in Edku lagoon $(3.4 \mathrm{~g} / \mathrm{l})$ is lower than average value (7.4 g/l) of Manzala (Abu Khatita et al., 2017) and Qarun lake (from 26.4 - $43.9 \mathrm{~g} / \mathrm{l})$ (Fathi and Flower, 2005).

The dissolved inorganic nitrogen comprises ammonia, nitrite and nitrate. The pathways of the nitrogen cycle are highly dependent on microbial activities and transformations, and one of the most important pathways in the nitrogen cycle is nitrification, the oxidation of ammonia to nitrite and sub-sequently to nitrate (Hovanec and Delong, 1996).

In this study, the highest values of inorganic nitrogen (ammonia; $1.9 \mathrm{mg} / \mathrm{l}$, nitrite $0.191 \mathrm{mg} / \mathrm{l}$ and nitrate $0.915 \mathrm{mg} / \mathrm{l}$ ) were recorded at station 1 for ammonia and nitrite and station 2 for nitrate, while the lowest values (1.3, 0.065 and $0.065 \mathrm{mg} / \mathrm{l}$, respectively) were observed at station 7 with an average value of $1.6,0.122$ and $0.475 \mathrm{mg} / \mathrm{l}$, respectively. The levels of inorganic nitrogen were increased in the middle part of the lagoon especially opposite to Kom Belag drain, which probably attributed to drainage water inflow to these areas which supply about $1100 \mathrm{t}$ of dissolved inorganic nitrogen annually (Shakweer, 2006). It is worth to mention that, the rate of the ammonification process increases especially at high temperature (Ali, 2008). Also increasing of nitrate can also be formed in water bodies through the oxidation of ammonia and nitrite

It can be observed a good correlation between ammonia and nitrate $(r=0.62)$ and nitrite and nitrate $(r=0.87)$. In general, the average concentration of nitrite and nitrate were 0.122 and $0.475 \mathrm{mg} / \mathrm{l}$, respectively, that greater than those at Manzala lagoon $(0.110$ and $0.18 \mathrm{mg} / \mathrm{l}$, respectively) (Abu Khatita et al., 2017). In the same context, the average concentration of nitrite is higher than the standard value of aquatic life $(0.065 \mathrm{mg} / \mathrm{l})$ (CCME, 2007).

Phosphate is not generally recognized as toxic to aquatic organisms and it is an important nutrient which can assist in stimulating the growth of aquatic organisms, particularly algae in fresh and brackish waters. Phosphorus (P) is the rate-limiting nutrient in the eutrophication of most freshwater ecosystems (Mainston and Parr, 2002). 
The maximum value of orthophosphate (O.P.) was $0.527 \mathrm{mg} / \mathrm{l}$ and recorded at station 1 , while the minimum value was $0.198 \mathrm{mg} / \mathrm{l}$ and recorded at station 7 . The spatial distribution shows that the eastern side of the lagoon is characterized by the highest values while the western side characterized by the lowest one. It is worth mentioning that drains to Edku lagoon supply about 650 t of dissolved inorganic phosphorus annually (Shakweer, 2006). In general, the average value of ortho-phosphate $(0.390 \mathrm{mg} / \mathrm{l})$ is greater than that of Manzala lagoon (0.210 mg/l) (Abu Khatita et al., 2017). Ferreira et al. (2011) recommended optimum range of orthophosphate $(0.01-0.20 \mathrm{mg} / \mathrm{l})$ for maximum growth and production of the most aquatic life which mean that, most part of the lagoon is under critical condition.

Chlorophyll-a is an important biological indicator for the algae biomass, and it is often considered as the main factor for assessing eutrophication (Jayaweera and Asaeda 1996; Yung et al., 1997; Zhou et al., 2004). Chlorophyll-a can be used as a non-specific indicator of the trophic status (level of pollution) of a water body (Håkanson et al., 2007). Algal growth is closely related to a variety of environmental water quality parameters such as total nitrogen, total phosphorus, light intensity, water temperature, pH and DO (Smith, 1983; Lovell and Konopka, 1985; Scholz, 2006).

The highest value was recorded at station 1 , being $102.7 \mu \mathrm{g} / \mathrm{l}$, while the lowest value was recorded at station 7 , being $51.3 \mu \mathrm{g} / \mathrm{l}$. The spatial distribution showed that the values decrease towards the northwestern part, while the middle part displays the highest values of chlorophyll-a. The highest values of chlorophyll-a are found in the areas exposed to drainage water containing high concentrations of nutrient salts (nitrite, nitrate, ammonia, orthophosphate, total phosphorus and silicate). High levels of nutrients cause algal blooms. It is worth to mention that there is a positive relation between chlorophylla and nutrient salts (ammonia $r=0.77$ and orthophosphate $r=0.78$ ) of Edku lagoon.

\section{Heavy Metals}

The concentration values of heavy metals in Edku lagoon are tabulated in Table 5 while spatial distribution of values are illustrated in Fig. 3. The obtained data revealed that heavy metals varied between 0.334 to $0.552 \mathrm{mg} / \mathrm{l}$ for $\mathrm{Fe}, 0.119$ to $0.401 \mathrm{mg} / \mathrm{l}$ for $\mathrm{Zn}$, 0.106 and $0.441 \mathrm{mg} / \mathrm{l}$ for $\mathrm{Cu}, 0.136$ to $0.424 \mathrm{mg} / \mathrm{l} \mathrm{Mn}, 0.031$ to $0.097 \mathrm{mg} / \mathrm{l}$ for $\mathrm{Pb}, 0.022$ to $0.064 \mathrm{mg} / \mathrm{l}$ for $\mathrm{Cd}$ and 0.02 to $0.08 \mu \mathrm{g} / \mathrm{l}$ for $\mathrm{Hg}$. The concentrations of heavy metals in water take the following sequence; $\mathrm{Fe}>\mathrm{Cu}>\mathrm{Mn}>\mathrm{Zn}>\mathrm{Pb}>\mathrm{Cd}>\mathrm{Hg}$. Spatially, concentrations of $\mathrm{Fe}, \mathrm{Mn}, \mathrm{Zn}, \mathrm{Cu}$ and $\mathrm{Cd}$ increase southward and eastward and decrease towards northwestern side of the lagoon, while concentrations of $\mathrm{Cd}$ and $\mathrm{Pb}$ decrease towards middle part and increase towards eastern and western parts of the lagoon. In 
general, the stations that affected by drains are more polluted by heavy metals, while the stations far from drains inputs are less. Shakweer (2006) mentioned that drains discharge $2 \times 10^{9} \mathrm{~m}^{3} \mathrm{yr}^{-1}$ of different type of effluent to lagoon. Alloway and Ayres (1997) stated that the domestic sewage added more amount of zinc. The correlation coefficient (based on Pearson's correlation matrix) between heavy metals content is presented in Table 7. Fe positively correlates with $\mathrm{Mn}(\mathrm{r}=0.82), \mathrm{Cu}(\mathrm{r}=0.80), \mathrm{Pb}(\mathrm{r}=0.25), \mathrm{Zn}(\mathrm{r}=0.88), \mathrm{Cd}(\mathrm{r}=$ $0.38)$ and $\mathrm{Hg}(\mathrm{r}=0.94)$. Moreover, $\mathrm{Zn}$ has a positive correlation with $\mathrm{Cu}(\mathrm{r}=0.99), \mathrm{Mn}(\mathrm{r}=$ $0.99)$ and $\mathrm{Hg}(\mathrm{r}=0.98)$. In addition, $\mathrm{Hg}$ correlates with $\mathrm{Mn}(\mathrm{r}=0.95)$, and $\mathrm{Cu}(\mathrm{r}=0.95)$ and $\mathrm{Pb}$ correlates with $\mathrm{Cd}(\mathrm{r}=0.98)$. Suresh et al. (2011) reported that, high correlation coefficient between the variables means their common source, mutual dependence and identical behavior during the transport. In general, the average value of heavy metals in Edku lagoon (Fe; $0.44 \mathrm{mg} / \mathrm{l}, \mathrm{Zn} ; 0.290 \mathrm{mg} / \mathrm{l}, \mathrm{Cu} ; 0.328 \mathrm{mg} / \mathrm{l}, \mathrm{Mn} ; 0.322 \mathrm{mg} / \mathrm{l}$ and Pb; $0.059 \mathrm{mg} / \mathrm{l}$ ) were lower than values of Manzala lagoon (Fe; $0.931 \mathrm{mg} / \mathrm{l}, \mathrm{Zn} ; 0.484 \mathrm{mg} / \mathrm{l}$, $\mathrm{Cu} ; 0.488 \mathrm{mg} / \mathrm{l}, \mathrm{Mn} ; 0.430 \mathrm{mg} / \mathrm{l}$ and $\mathrm{Pb} ; 0.161 \mathrm{mg} / \mathrm{l}$ ) (Abu Khatita et al., 2017) but greater than those of Bardawil lagoon (Fe; $0.29 \mathrm{mg} / \mathrm{l}, \mathrm{Zn} ; 0.17 \mathrm{mg} / \mathrm{l}, \mathrm{Cu} ; 0.01 \mathrm{mg} / \mathrm{l}, \mathrm{Mn}$; $0.04 \mathrm{mg} / \mathrm{l}$ and $\mathrm{Pb}$; $0.04 \mathrm{mg} / \mathrm{l}$ ) (El-Kassas et al., 2016) and El-Mex Bay (Fe; $0.022 \mathrm{mg} / \mathrm{l}$, $\mathrm{Zn} ; 0.005 \mathrm{mg} / \mathrm{l}, \mathrm{Cu} ; 0.002 \mathrm{mg} / \mathrm{l}, \mathrm{Mn} ; 0.322 \mathrm{mg} / \mathrm{l}$ and $\mathrm{Pb} ; 0.004 \mathrm{mg} / \mathrm{l}$ ) (Abbas, 2015). Unfortunately, the average concentration of $\mathrm{Cd}$ in Edku lagoon reach highest concentration $(0.040 \mathrm{mg} / \mathrm{l})$ compared to Manzala lagoon and El-Mex Bay (0.034 and $0.0003 \mathrm{mg} / \mathrm{l}$, respectively). The average value of heavy metals compared with different standard in Table 6. Since average value of $\mathrm{Fe}, \mathrm{Pb}$ and $\mathrm{Cd}$ violate the maximum permissible limits of Canadian Council of Ministers of the Environment (CCME, 2007), Egyptian Organization for Standardization and Quality (EOS, 2005), United State Environmental Protection Agency (USEPA, 2009) and World Health Organization (WHO, 2006). 
Table 5: Physico-chemical parameters and heavy metals concentrations in water samples of Edku lagoon.

\begin{tabular}{|c|c|c|c|c|c|c|c|c|}
\hline 总 & 窇 & $\bar{a}$ & 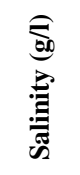 & 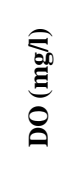 & 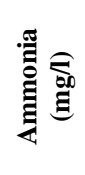 & 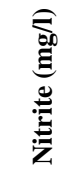 & 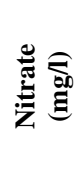 & 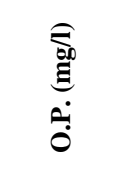 \\
\hline 1 & 28 & 7.7 & 1.2 & $\overline{4.5}$ & 1.9 & 0.191 & 0.792 & 0.527 \\
\hline 2 & 28 & 7.62 & 1.9 & 3.9 & 1.6 & 0.163 & 0.915 & 0.456 \\
\hline 3 & 28.3 & 7.7 & 1.8 & 3.5 & 1.5 & 0.166 & 0.578 & 0.496 \\
\hline 4 & 29.1 & 8.32 & 2.3 & 7.6 & 1.7 & 0.067 & 0.308 & 0.284 \\
\hline 5 & 28.9 & 8.68 & 3.1 & 12.5 & 1.5 & 0.101 & 0.288 & 0.293 \\
\hline 6 & 30.3 & 8.9 & 1.3 & 7.5 & 1.4 & 0.104 & 0.217 & 0.475 \\
\hline 7 & 29.1 & 8.6 & 12.2 & 7.5 & 1.3 & 0.065 & 0.227 & 0.198 \\
\hline Max. & 30.3 & 8.9 & 12.2 & 12.5 & 1.9 & 0.191 & 0.915 & 0.527 \\
\hline Mini. & 28 & 7.62 & 1.2 & 3.5 & 1.3 & 0.065 & 0.217 & 0.198 \\
\hline Average & 28.8 & 8.21 & 3.4 & 6.7 & 1.5 & 0.122 & 0.475 & 0.389 \\
\hline 产 & 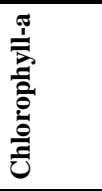 & 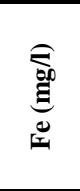 & 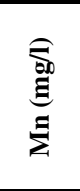 & 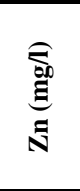 & 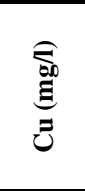 & 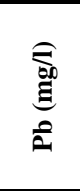 & 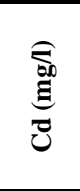 & 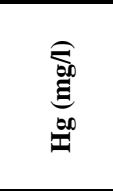 \\
\hline 1 & 102.73 & 0.402 & 0.332 & 0.289 & 0.347 & 0.046 & 0.028 & 0.00005 \\
\hline 2 & 97.32 & 0.415 & 0.339 & 0.308 & 0.352 & 0.051 & 0.031 & 0.00005 \\
\hline 3 & 100.97 & 0.467 & 0.348 & 0.313 & 0.377 & 0.054 & 0.036 & 0.00006 \\
\hline 4 & 88.87 & 0.533 & 0.413 & 0.387 & 0.425 & 0.064 & 0.048 & 0.00007 \\
\hline 5 & 73.77 & 0.334 & 0.264 & 0.212 & 0.251 & 0.031 & 0.022 & 0.00003 \\
\hline 6 & 75.24 & 0.552 & 0.424 & 0.401 & 0.441 & 0.071 & 0.052 & 0.00008 \\
\hline 7 & 51.32 & 0.367 & 0.136 & 0.119 & 0.106 & 0.097 & 0.064 & 0.00002 \\
\hline Max. & 102.73 & 0.552 & 0.424 & 0.401 & 0.441 & 0.097 & 0.064 & 0.00008 \\
\hline Mini. & 51.32 & 0.334 & 0.136 & 0.119 & 0.106 & 0.031 & 0.022 & 0.00002 \\
\hline Average & 84.31 & 0.438 & 0.322 & 0.289 & 0.328 & 0.059 & 0.040 & $5.14 \mathrm{E}-05$ \\
\hline
\end{tabular}

Table 6: Heavy metal concentrations in water from Edku lagoon in relation to other locations in Egypt and standard limits of the water parameters.

\begin{tabular}{cccccccc}
\hline & $\begin{array}{c}\mathbf{F e} \\
(\mathbf{m g} / \mathbf{l})\end{array}$ & $\begin{array}{c}\mathbf{M n} \\
(\mathbf{m g} / \mathbf{l})\end{array}$ & $\begin{array}{c}\mathbf{Z n} \\
(\mathbf{m g} / \mathbf{l})\end{array}$ & $\begin{array}{c}\mathbf{C u} \\
(\mathbf{m g} / \mathbf{l})\end{array}$ & $\begin{array}{c}\mathbf{P b} \\
(\mathbf{m g} / \mathbf{l})\end{array}$ & $\begin{array}{c}\mathbf{C d} \\
(\mathbf{m g} / \mathbf{l})\end{array}$ & $\mathbf{H g}(\mathbf{m g} / \mathbf{l})$ \\
\hline $\begin{array}{c}\text { Edku } \\
\text { Manzala (Abu Khatita } e t\end{array}$ & 0.439 & 0.322 & 0.290 & 0.328 & 0.059 & 0.0401 & 0.000051 \\
$\begin{array}{c}\text { al., 2017) } \\
\text { El-Mex Bay (Abbas, }\end{array}$ & 0.931 & 0.43 & 0.484 & 0.488 & 0.161 & 0.034 & - \\
$\begin{array}{c}\text { 2015) } \\
\text { Bardawil (El-Sayed, }\end{array}$ & 0.022 & - & 0.005 & 0.002 & 0.004 & 0.0003 & - \\
$\quad 0.29$ & 0.04 & 0.17 & 0.01 & 0.04 & - & - \\
$\quad \begin{array}{c}\text { 2014) } \\
\text { CCME (2007) }\end{array}$ & 0.3 & 0.05 & 0.05 & 0.004 & 0.007 & 0.001 & 0.000016 \\
$\quad$ EOS (2005) & 0.3 & 0.1 & 3 & 2 & 0.01 & 0.003 & - \\
$\quad$ USEPA (2009) & 0.3 & 0.05 & 5 & 1 & 0.015 & 0.005 & 0.002 \\
WHO (2006) & 0.3 & 0.4 & 3 & 2 & 0.01 & 0.003 & 0.001 \\
\hline
\end{tabular}




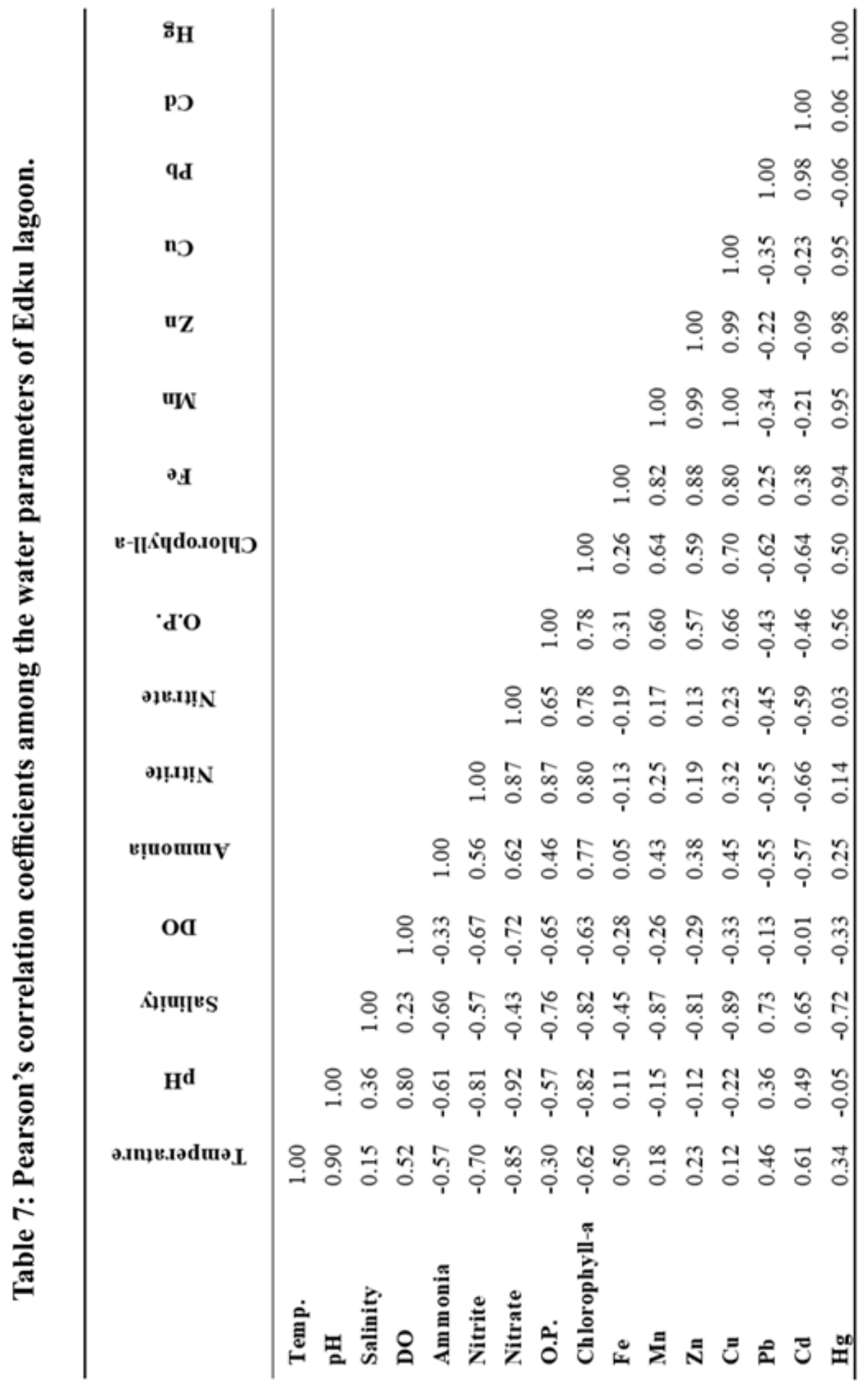



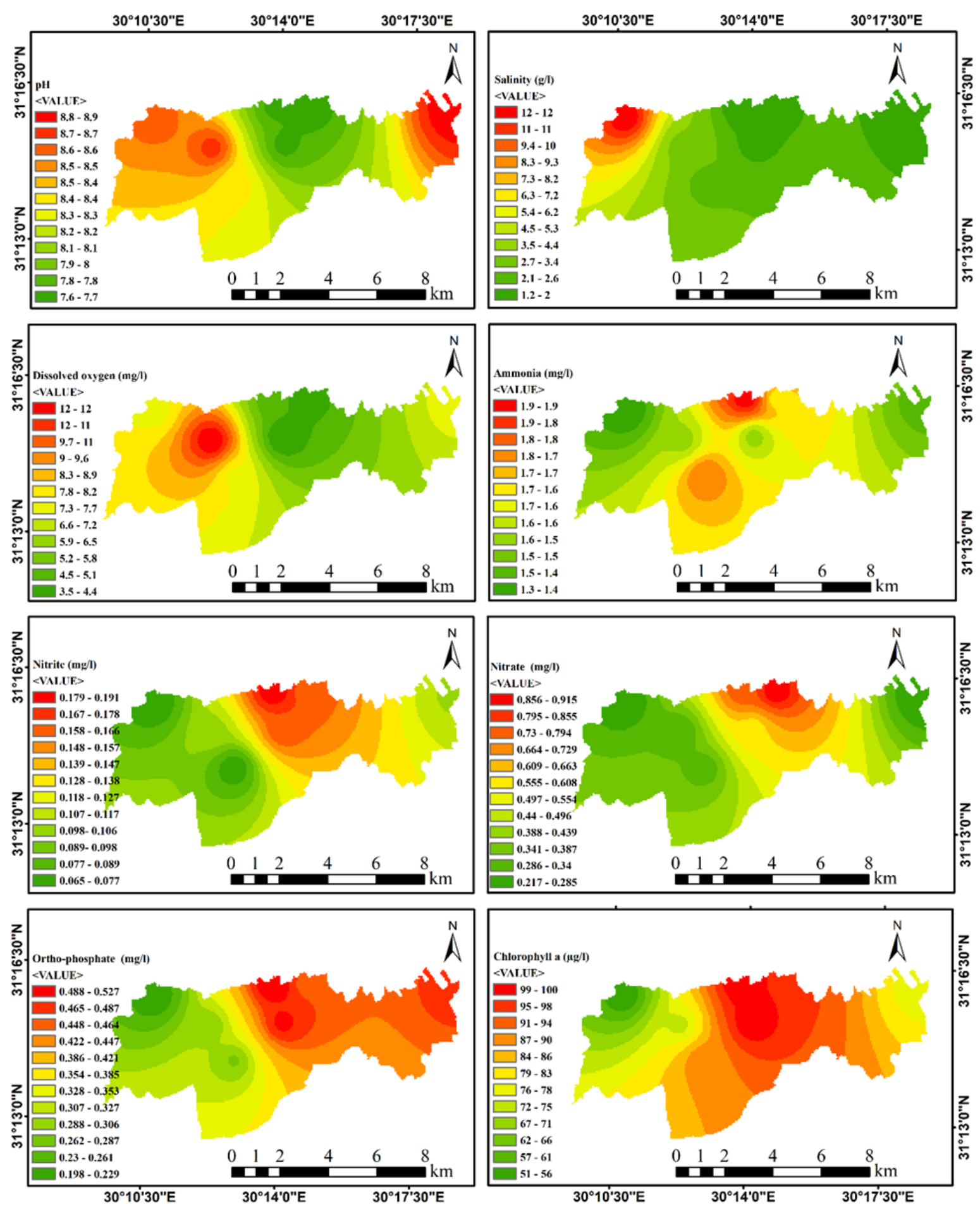

Fig. 2: Spatial distribution of physico-chemical parameters in water samples of Edku lagoon. 

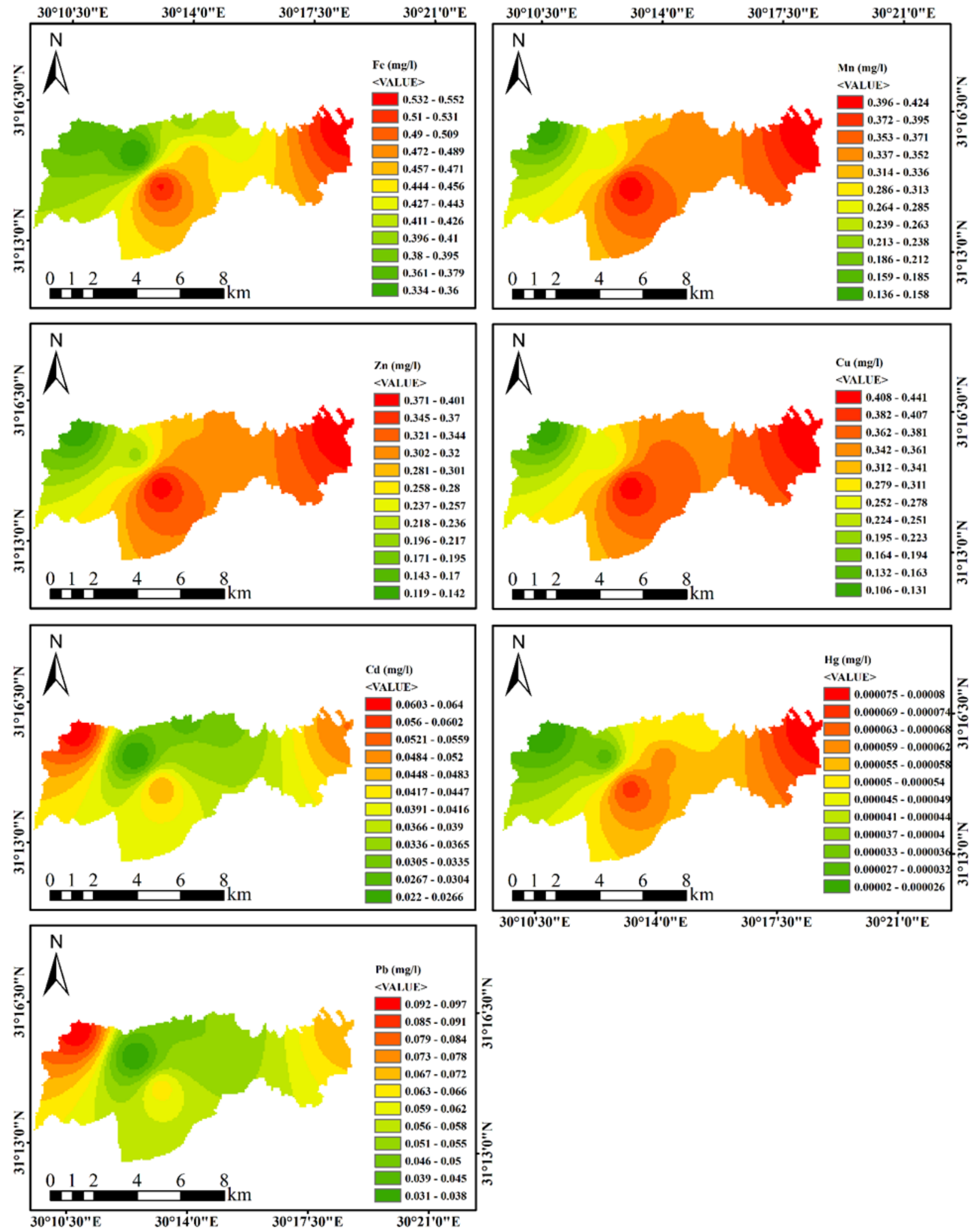

Fig. 3: Spatial distribution of heavy metal concentrations in water samples of Edku lagoon. 


\section{Eutrophication Index (E.I.)}

Eutrophication Index (E.I.) is a multi-metric (combination of nutrients and chlorophyll-a) tool for the assessment of trophic status proposed by Primpas $\boldsymbol{e t}$ al. (2010). The calculated values of E.I. varied between 0.50 and 0.95 . Consequently, stations 3-7 are under mesotrophic condition while stations 1 and 2 are under eutrophic condition (Fig. 4) where the water exhibit poor class of ecological quality according to the E.I. scale proposed by Primpas et al. (2010) (Table 9).

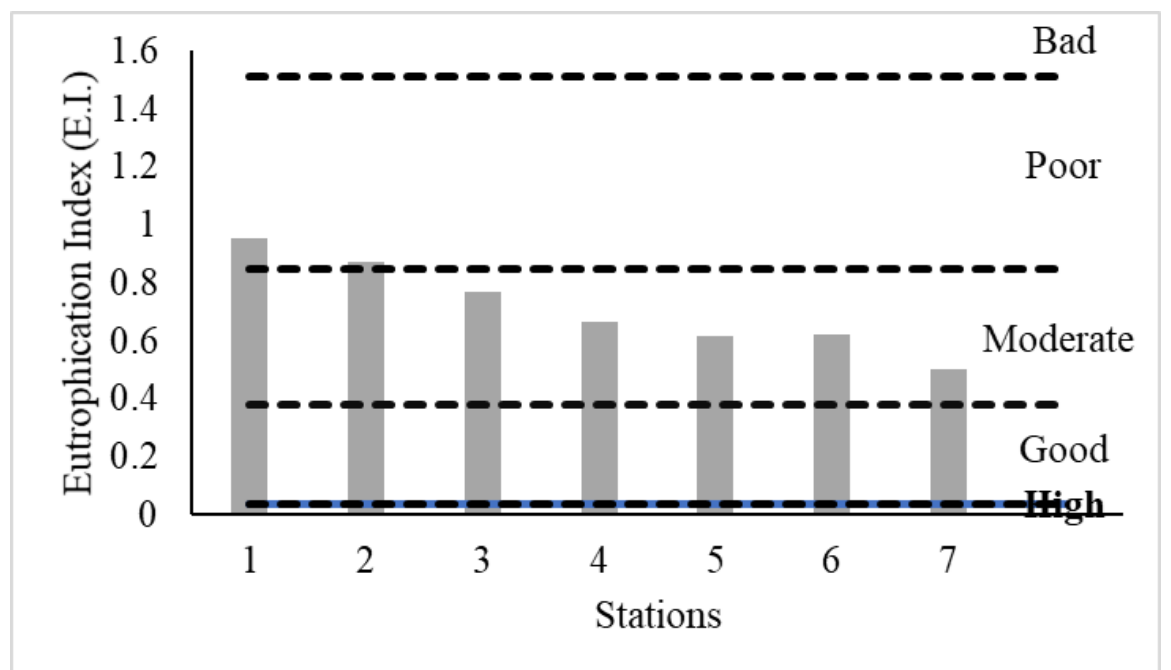

Fig. 4. Distribution of Eutrophication Index (E.I.) in sample stations.

\section{Water Quality Index (WQI)}

The WQI was apply on water quality parameters to display an overall picture of water quality of Edku lagoon. The obtained values were ranged from 818 at station 5 to 1566 at station 6. Overall, all sample classified as "bad water " (Fig. 5 and Table 9) and consequently these waters unsuitable for most of organisms which reflect the impact of discharging wastewater.

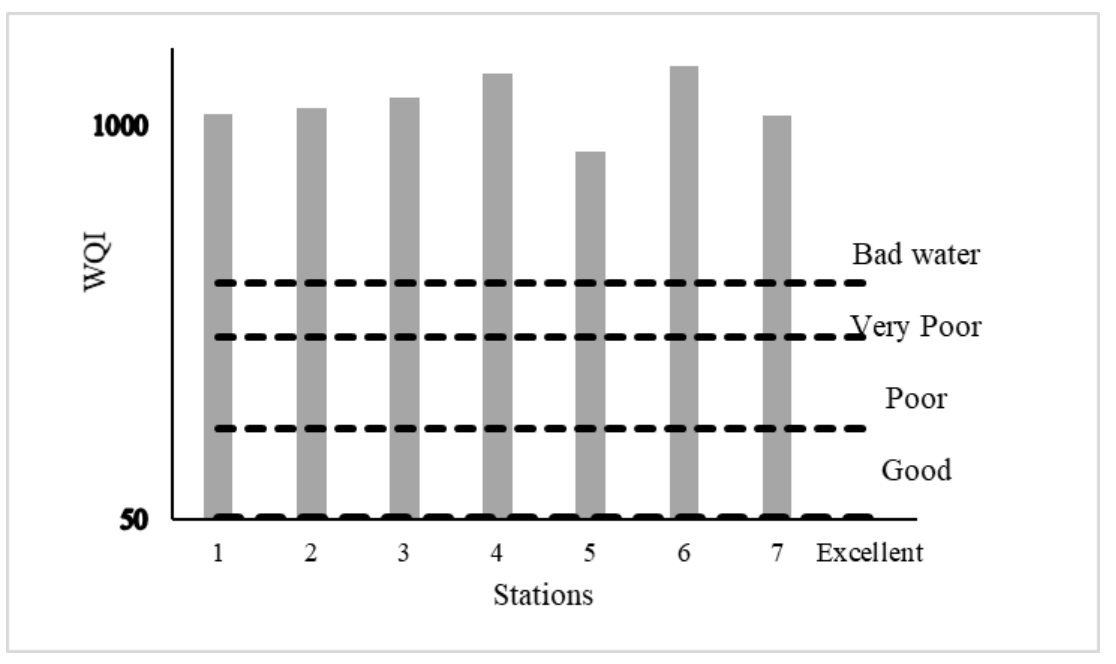

Fig. 5. Distribution of water quality index (WQI) in sample stations. 


\section{Pollution Assessment Indices \\ Pollution Index (PI)}

Studied heavy metals in the lagoon were ordered as $\mathrm{Cu}>\mathrm{Cd}>\mathrm{Pb}>\mathrm{Mn}>\mathrm{Zn}>\mathrm{Hg}>\mathrm{Fe}$ based on calculated PI (Table 8) where, Fe shows slight effect on aquatic life (PI=1.07). However, $\mathrm{Hg}(\mathrm{PI}=2.58)$ shows moderate effect while $\mathrm{Mn}$ and $\mathrm{Zn}(\mathrm{PI}=4.45$ and 4.18, respectively) displays strong effect on aquatic life. Moreover, $\mathrm{Cu}, \mathrm{Pb}$ and $\mathrm{Cd}(\mathrm{PI}=56.70$, 7.27 and 33.84, respectively) illustrates Serious effect on aquatic life.

Table: 8 Pollution index of the measured metals in water of Edku lagoon.

\begin{tabular}{ccc}
\hline Parameters & $\begin{array}{c}\text { Pollution index } \\
\text { (PI) }\end{array}$ & Effect \\
\hline $\mathbf{F e}$ & 1.075304 & Slightly affected \\
$\mathbf{M n}$ & 4.452774 & Strongly affected \\
$\mathbf{Z n}$ & 4.182846 & Strongly affected \\
$\mathbf{C u}$ & 56.69504 & Seriously affected \\
$\mathbf{P b}$ & 7.2738 & Seriously affected \\
$\mathbf{C d}$ & 33.83785 & Seriously affected \\
$\mathbf{H g}$ & 2.576941 & Moderately affected \\
\hline
\end{tabular}

\section{Heavy Metal Evaluation Index (HEI)}

Heavy metal evaluation index was applied to assess the quality of surface water with respect to heavy metal contents. The values of HEI varied from 35.27 to 90.70 (Table 9) with an average of 61.89. In general, all values were found to be higher than 20, indicating high pollution status of heavy metals in the examined lagoon water.

\section{Contamination Index $\left(\mathbf{C}_{\mathbf{d}}\right)$}

The contamination index $\left(\mathrm{C}_{\mathrm{d}}\right)$ value varied from 28.27 to 83.70 (Table 9$)$ with an average of 54.89. Overall, all examined water samples indicating very high contamination of lagoon water by the heavy metals.

\section{Heavy Metal Pollution Index (HPI)}

The HPI is based on the composite influence of the individual heavy metals on the overall water quality (Mohan et al., 1996). The critical condition arises if the index reaches the value of 100 . The result shows that all values of HPI are greater than the critical value for drinking water (Fig. 6 and Table 10) based on Prasad and Bose (2001).

\section{Human Health Risk Assessment}

The results obtained for human health risk assessment estimated from the hazard quotient $\left(\mathrm{HQ}_{\text {dermal }}\right)$ using the USEPA risk assessment models for all monitoring data of heavy metals, for non-cancer effect, are presented in Table 11. The $\mathrm{HQ}_{\text {dermal }}$ of most heavy metals ( $\mathrm{Fe}, \mathrm{Mn}, \mathrm{Zn}, \mathrm{Cu}, \mathrm{Pb}$ and $\mathrm{Hg}$ ) were lower than one. The $\mathrm{HQ}<1$ meaning that these non-carcinogenic pollutants may have not negative health effects. On the other hand, $\mathrm{HQ}_{\mathrm{dermal}}$ for $\mathrm{Cd}$ in some water sample (samples 3, 4, 6 and 7) violate the unity (Fig. 7). Tripathee et al., (2016) noted that pollutants may pose potential adverse health effects if the HQ value of the metal is greater than unity. 
Table 9: Water quality index (WQI), eutrophication index (E.I.), heavy metal evaluation index (HEI) and contamination index $\left(C_{d}\right)$ of water samples of Edku lagoon.

\begin{tabular}{ccccccccc}
\hline \multirow{2}{*}{ Stations } & \multicolumn{2}{c}{$\begin{array}{c}\text { Water quality } \\
\text { index (WQI) }\end{array}$} & \multicolumn{2}{c}{$\begin{array}{c}\text { Eutrophication } \\
\text { Index (E.I.) }\end{array}$} & \multicolumn{2}{c}{$\begin{array}{c}\text { Heavy metal } \\
\text { evaluation index }(\text { HEI })\end{array}$} & \multicolumn{2}{c}{$\begin{array}{c}\text { Contamination } \\
\text { index }\left(\mathbf{C}_{\mathbf{d}}\right)\end{array}$} \\
\cline { 2 - 9 } & value & Rank & value & status & value & Rank & value & Rank \\
\hline 1 & 1086 & Bad water & 0.954 & Eutrophic/poor & 49.10 & Highly polluted & 42.10 & high \\
2 & 1133 & Bad water & $\overline{0.875}$ & Eutrophic/poor & 53.65 & Highly polluted & 46.65 & high \\
3 & 1235 & Bad water & 0.772 & Mesotrophic/moderate & 57.79 & Highly polluted & 50.79 & high \\
4 & 1473 & Bad water & 0.665 & Mesotrophic/moderate & 70.16 & Highly polluted & 63.16 & high \\
5 & 818 & Bad water & 0.615 & Mesotrophic/moderate & 35.27 & Highly polluted & 28.27 & high \\
6 & 1566 & Bad water & 0.621 & Mesotrophic/moderate & 76.51 & Highly polluted & 69.51 & high \\
7 & 1072 & Bad water & 0.502 & Mesotrophic/moderate & 90.70 & Highly polluted & 83.70 & high \\
Min. & 818 & & 0.502 & & 35.27 & & 28.27 & \\
Max. & 1566 & & 0.955 & & 90.70 & & 83.70 & \\
Average & 1198 & & 0.715 & & 61.89 & & 54.89 & \\
\hline
\end{tabular}

Table 10: Heavy metal pollution index (HPI) of water samples of Edku lagoon.

\begin{tabular}{|c|c|c|c|c|c|c|c|}
\hline \multirow{2}{*}{ Stations } & \multicolumn{6}{|c|}{ Sub-index (Qi) } & \multirow{2}{*}{ HPI } \\
\hline & $\mathbf{F e}$ & Mn & $\mathbf{Z n}$ & $\mathbf{C u}$ & $\mathbf{P b}$ & Cd & \\
\hline 1 & 1.01 & -0.84 & 0.03 & -0.17 & 28.00 & 375 & 392.7 \\
\hline 2 & 1.08 & -0.81 & 0.03 & -0.16 & 31.89 & 420 & 440.5 \\
\hline 3 & 1.34 & -0.76 & 0.03 & -0.16 & 34.22 & 495 & 516.1 \\
\hline 4 & 1.67 & -0.44 & 0.03 & -0.16 & 42.00 & 675 & 699.8 \\
\hline 5 & 0.67 & -1.18 & 0.03 & -0.17 & 16.33 & 285 & 293.0 \\
\hline 6 & 1.76 & -0.38 & 0.03 & -0.16 & 47.44 & 735 & 763.7 \\
\hline 7 & 0.84 & -1.82 & 0.03 & -0.19 & 67.67 & 915 & 956.5 \\
\hline
\end{tabular}

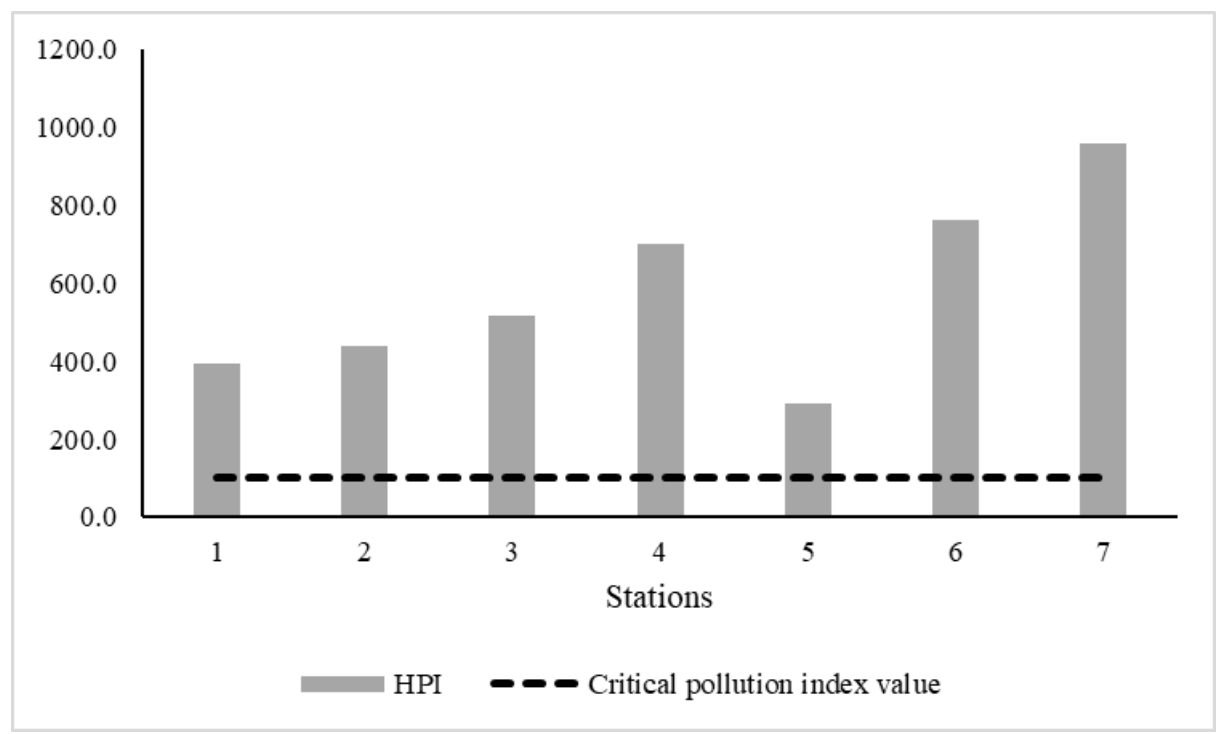

Fig. 6. Distribution of heavy metal pollution index (HPI) in sample stations. 
Table 11: Hazard Quotient $\left(H Q_{\text {dermal }}\right)$ of different metals for water samples of Edku lagoon.

\begin{tabular}{cccccccc}
\hline \multirow{2}{*}{ parameters } & \multicolumn{7}{c}{ Hazard Quotient $\left(\mathbf{H Q}_{\text {dermal }}\right)$} \\
\cline { 2 - 8 } & $\mathbf{1}$ & $\mathbf{2}$ & $\mathbf{3}$ & $\mathbf{4}$ & $\mathbf{5}$ & $\mathbf{6}$ & $\mathbf{7}$ \\
\hline $\mathrm{Fe}$ & 0.00140 & 0.00145 & 0.00163 & 0.00186 & 0.00116 & 0.00192 & 0.00128 \\
$\mathrm{Mn}$ & 0.06512 & 0.06650 & 0.06826 & 0.08101 & 0.05178 & 0.08317 & 0.02668 \\
$\mathrm{Zn}$ & 0.00045 & 0.00048 & 0.00049 & 0.00061 & 0.00033 & 0.00063 & 0.00019 \\
$\mathrm{Cu}$ & 0.00454 & 0.00460 & 0.00493 & 0.00556 & 0.00328 & 0.00577 & 0.00139 \\
$\mathrm{~Pb}$ & 0.01719 & 0.01905 & 0.02018 & 0.02391 & 0.01158 & 0.02653 & 0.03624 \\
$\mathrm{Cd}$ & 0.87877 & 0.97292 & 1.12985 & 1.50646 & 0.69046 & 1.63200 & 2.00862 \\
$\mathrm{Hg}$ & 0.02615 & 0.02615 & 0.03138 & 0.03662 & 0.01569 & 0.04185 & 0.01046 \\
\hline
\end{tabular}

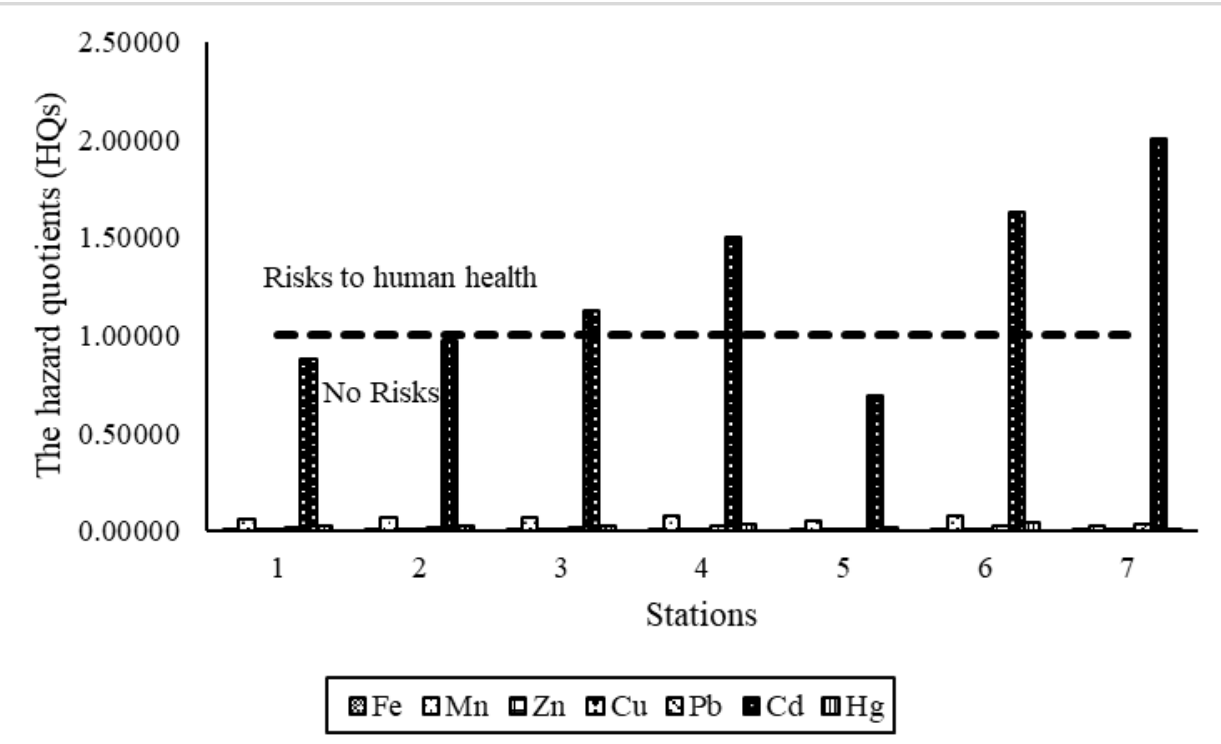

Fig. 7. Distribution of the hazard quotient $\left(H Q_{\text {dermal }}\right)$ for different metals in sample stations.

\section{CONCLUSION}

Edku lagoon exposed to different anthropogenic stress. Wastewater effluents discharging adversely impacts the physico-chemical parameters of the lagoon water. Discharging process lead to increasing the levels of ammonia, nitrite, nitrate, orthophosphate and chlorophyll- $a$ in the lagoon particularly in the eastern part. Moreover, the studied heavy metals ( $\mathrm{Fe}, \mathrm{Mn}, \mathrm{Zn}, \mathrm{Cu}, \mathrm{Pb}, \mathrm{Cd}$ and $\mathrm{Hg}$ ) concentration violate the maximum permissible limits. The trophic index used in this research has helped to range the trophic level of Edku lagoon from mesotrophic to eutrophic condition. Water quality 
index indicates that the lagoon water is classified as bad water for the aquatic life. Furthermore, the results of HPI, HEI and $\mathrm{C}_{\mathrm{d}}$ showed that the lagoon water is highly contaminated by heavy metals, while PI indicate that the lagoon water varied from slightly affected to seriously affected by heavy metals. Human health risk assessment revealed that, $\mathrm{HQ}_{\text {dermal }}$ for $\mathrm{Cd}$ in some water sample violate the unity which may pose potential adverse health effects. The results of this paper may be helpful the for development of the lagoon. Hence, removal of heavy metals from drains before discharging to lagoon water is important to protect the aquatic life there.

\section{ACKNOWLEDGEMENT}

We appreciate Dr. Alam Eldeen Farouk, Central Laboratory for Aquaculture Research, Egypt, for his help and support in the analyses and laboratory work. We are grateful to the reviewers for their helpful reviews to improve the original manuscript.

\section{REFERENCES}

Abbas, M. M. (2015). Accumulation of heavy metals in the water, sediment and some fish species inhabiting El-Mex Bay, Alexandria, Egypt. M. Sc. Thesis, Fac. Sci., Al Azhar Univ, $385 \mathrm{p}$.

Abdel-Hamid, E.A.A. (2017). Assessment of water quality and Bacterial Contamination in Water, Sediments and Fish of Lake Manzala. Egy. J. Aquac., 7 (1): 55-75.

Abu Khatita, A.M.; Shaker, I.M. and Shetaia, S. A. (2017). Water quality assessment and potential health risk of Manzala lake-Egypt. Al Azhar Bulletin of Science, 9: 119136.

Al Sayes, A.; Radwan, A. and Shakweer, L. (2007). Impact of drainage water inflow on the environmental conditions and fishery resources of Lake Borollus. Egyptian J. Aquat. Res. 33: 312-351.

Al- Ani, M.Y.; Al- Nakib, S.M.; Ritha, N.M. and Nouri, A. H. (1987). Water quality index applied to the classification and zoning of Al- Jaysh canal, Baghdad-Iraq. Journal of Environmental Science \& Health Part A, 22(4): 305-319.

Ali, M. H. (2008). Assessment of some water quality characteristics and determination of some heavy metals in Lake Manzala, Egypt. J. Aquat. Biol \& Fish, 5(3): 17-30.

Alloway, B., and Ayres, D. C. (1997). Chemical principles of environmental pollution. CRC press.

Alobaidy, A. H. M.; Abid, H. S. and Maulood, B. K. (2010). Application of water quality index for assessment of Dokan lake ecosystem, Kurdistan region. Iraq. J Water Resour Prot, 2: 792-798.

Ameh, E. G. (2013). Geo-statistics and heavy metal indexing of surface water around Okaba coal mines, Kogi State, Nigeria. Asian Journal of Environmental Science, 8(1): 18 . 
APHA (American Public Health Association), (2000). Standard Methods for the Examination of Water and Wastewater (16 ${ }^{\text {th }}$ edition). Washington, D.C.

Caeiro, S.; Costa, M. H.; Ramos, T. B.; Fernandes, F.; Silveira, N.; Coimbra, A.; ... and Painho, M. (2005). Assessing heavy metal contamination in Sado Estuary sediment: an index analysis approach. Ecological indicators, 5(2): 151-169.

CCME (Canadian Council of Ministers of the Environment), (2007). For the protection of aquatic life 2007. In: Canadian environmental quality guidelines, 1999, Canadian Council of Ministers of the Environment, 1999, Winnipeg.

Chen, Z.; Salem, A.; Xu, Z. and Zhang, W. (2010). Ecological implications of heavy metal concentrations in the sediments of Burullus Lagoon of Nile Delta, Egypt. Estuarine, Coastal and Shelf Science, 86(3): 491-498.

Ebrahimpour, M. and Mushrifah, I. (2010). Seasonal variation of cadmium, copper, and lead concentrations in fish from a freshwater lake. Biological trace element research, 138(1-3): 190-201.

Edet, A. E. and Offiong, O. E. (2002). Evaluation of water quality pollution indices for heavy metal contamination monitoring. A study case from Akpabuyo-Odukpani area, Lower Cross River Basin (southeastern Nigeria). GeoJournal, 57(4): 295-304.

El-Enany, H. R. (2004). Ecological and biological studies on Lake El-Manzalah with special reference to their water quality and sediment productivity. M. Sc. Thesis, Fac. Sci., Al Azhar Univ, 386 p.

El-Kassas, H. Y.; Nassar, M. Z. A. and Gharib, S. M. (2016). Study of phytoplankton in a natural hypersaline lagoon in a desert area (Bardawil Lagoon in Northern Sinai, Egypt). Rendiconti Lincei, 27(3): 483-493.

El-Sayed, A. F. (2014). Studies on Water Quality, Pollution by Heavy Metals in Water, Soil and Fish and Stock Assessment in Bardawil Lake. Ph.D. Thesis, Fac. Sci., Al-Azhar Univ. 292 p.

El-Shahat, E., (1999). Limnology studies on Lake Bardawil. Ph. D. Thesis. Fac. Sci. Suez Canal Univ.

EOS (Egyptian Organization for Standardization and Quality) (2005). Egyptian drinking water quality standards, 2007. Ministry of Health, Population Decision number, $458 \mathrm{p}$.

Fathi, A. A. and Flower, R. J. (2005). Water quality and phytoplankton communities in Lake Qarun (Egypt). Aquatic Sciences, 67(3): 350-362.

Ferreira, N. C.; Bonetti, C. and Seiffert, W. Q. (2011). Hydrological and water quality indices as management tools in marine shrimp culture. Aquaculture, 318(3-4): 425-433.

Håkanson, L.; Bryhn, A. C. and Hytteborn, J. K. (2007). On the issue of limiting nutrient and predictions of cyanobacteria in aquatic systems. Science of the Total Environment, 379(1): 89-108. 
Hovanec, T. A. and DeLong, E. F. (1996). Comparative analysis of nitrifying bacteria associated with freshwater and marine aquaria. Appl. Environ. Microbiol., 62(8): 28882896.

Jaishankar, M.; Tseten, T.; Anbalagan, N.; Mathew, B. B. and Beeregowda, K. N. (2014). Toxicity, mechanism and health effects of some heavy metals. Interdisciplinary toxicology, 7(2): 60-72.

Jayaweera, M. and Asaeda, T. (1996). Modeling of biomanipulation in shallow, eutrophic lakes: An application to Lake Bleiswijkse Zoom, the Netherlands. Ecological Modelling, 85(2-3): 113-127.

Jordan, Y. C.; Ghulam, A. and Hartling, S. (2014). Traits of surface water pollution under climate and land use changes: A remote sensing and hydrological modeling approach. Earth-Science Reviews, 128: 181-195.

Khalil, M. K. and Rifaat, A. E. (2013). Seasonal fluxes of phosphate across the sedimentwater interface in Edku Lagoon, Egypt. Oceanologia, 55(1): 219-233.

Khalil, M. T. (1990). The physical and chemical environment of Lake Manzala, Egypt. Hydrobiologia, 196(3): 193-199.

Klontz, G. W. (1993). Environmental requirements and environmental diseases of salmonids. Fish Medicine. WB Saunders, Philadelphia, 333-342.

Kumar, V.; Parihar, R. D.; Sharma, A.; Bakshi, P.; Sidhu, G. P. S.; Bali, A. S.; Karaouzas, I.; Bhardwaj, R.; Thukral, A.K.; Gyasi-Agyei, Y. and Rodrigo-Comino, J. (2019). Global evaluation of heavy metal content in surface water bodies: A metaanalysis using heavy metal pollution indices and multivariate statistical analyses. Chemosphere, 124364.

Lovell, C. R. and Konopka, A. (1985). Excretion of photosynthetically fixed organic carbon by metalimnetic phytoplankton. Microbial Ecology, 11(1): 1-9.

Mainstone, C. P. and Parr, W. (2002). Phosphorus in rivers-ecology and management. Science of the Total Environment, 282: 25-47.

Meng, Q.; Zhang, J.; Zhang, Z. and Wu, T. (2016). Geochemistry of dissolved trace elements and heavy metals in the Dan River Drainage (China): distribution, sources, and water quality assessment. Environmental Science and Pollution Research, 23(8): 80918103.

Mohan, S. V.; Nithila, P. and Reddy, S. J. (1996). Estimation of heavy metals in drinking water and development of heavy metal pollution index. Journal of Environmental Science \& Health Part A, 31(2): 283-289.

Moufaddal, W.; El-Sayed, E. and Deghady, E. (2008). Updating morphometric and edaphic information of lakes Edku and Burullus, northern Egypt, with the aid of satellite remote sensing. Egypt J Aquat Res, 34: 291-310.

Oczkowski, A. J. and Nixon, S. W. (2010). Lagoons of the Nile Delta, in Kennish, M. J. and Paerl, H. W. 2010. Coastal Lagoons. CRC Press. 253-282. 
Okbah, M. A. and El-Gohary, S. E. (2002). Physical and chemical characteristics of Lake Edku water, Egypt. Mediterranean Marine Science, 3(2): 27-39.

Prasad, B. and Bose, J. (2001). Evaluation of the heavy metal pollution index for surface and spring water near a limestone mining area of the lower Himalayas. Environmental Geology, 41(1-2): 183-188.

Primpas, I.; Tsirtsis, G.; Karydis, M. and Kokkoris, G. D. (2010). Principal component analysis: Development of a multivariate index for assessing eutrophication according to the European water framework directive. Ecological Indicators, 10(2): 178-183.

Ravikumar, P.; Mehmood, M. A. and Somashekar, R. K. (2013). Water quality index to determine the surface water quality of Sankey tank and Mallathahalli lake, Bangalore urban district, Karnataka, India. Applied water science, 3(1): 247-261.

Reddy S.J. (1995). Encyclopedia of environmental pollution and control. Environmental Media, Karlla, India 1-342 pp.

Saad, M.A.H. (2003). Impact of diffuse pollution on the socio-economic development opportunities in the coastal Nile delta lakes. Diffuse Pollution Conference Dublin 2003 ECSA, 5: 6-81.

Salomons, W. and Förstner, U. (2012). Metals in the Hydrocycle. Springer Science \& Business Media.

Sarria-Villa, R.; Ocampo-Duque, W.; Páez, M. and Schuhmacher, M. (2016). Presence of PAHs in water and sediments of the Colombian Cauca River during heavy rain episodes, and implications for risk assessment. Science of the Total Environment, 540: 455-465.

Scholz, M. (2006). Wetland systems to control urban runoff. Amsterdam: Elsevier.

Shakweer, L. (2005). Ecological and fisheries development of Lake Manzalah (Egypt).1Hydrography and chemistry of Lake Manzalah. Bulletin of the National Institute of Oceanography and Fisheries, 31(1): 251-270.

Shakweer, L. (2006). Impacts of drainage water discharge on the water chemistry of Lake Edku. Egyptian Journal of Aquatic Research, 32(1): 264-282.

Sheykhi, V. and Moore, F. (2012). Geochemical characterization of Kor River water quality, fars province, Southwest Iran. Water Quality, Exposure and Health, 4(1): 25-38.

Siegel, F. R. (2002). Environmental geochemistry of potentially toxic metals (Vol. 32). Berlin: Springer.

Smith, V. H. (1983). Low nitrogen to phosphorus ratios favour dominance by blue-green algae in lake phytoplankton. Science, 221(4611): 669-671.

Soliman, A. S.; Wang, X.; Stanley, J. D.; El-Ghawalby, N.; Bondy, M. L.; Ezzat, F.; Soultan, A.; Abdel-Wahab, M.; Fathy, O.; Ebidi, G. and Abdel-Karim, N. (2006). Geographical clustering of pancreatic cancers in the Northeast Nile Delta region of Egypt. Archives of environmental contamination and toxicology, 51(1): 142-148. 
Strom, S. M. (2008). Total mercury and methylmercury residues in river otters (Lutra canadensis) from Wisconsin. Archives of Environmental Contamination and Toxicology, 54(3): 546-554.

Suresh, G.; Ramasamy, V.; Meenakshisundaram, V.; Venkatachalapathy, R. and Ponnusamy, V. (2011). Influence of mineralogical and heavy metal composition on natural radionuclide concentrations in the river sediments. Applied Radiation and Isotopes, 69(10): 1466-1474.

Tripathee, L.; Kang, S.; Sharma, C. M.; Rupakheti, D.; Paudyal, R.; Huang, J. and Sillanpää, M. (2016). Preliminary health risk assessment of potentially toxic metals in surface water of the Himalayan Rivers, Nepal. Bulletin of environmental contamination and toxicology, 97(6): 855-862.

Tscheikner-Gratl, F.; Bellos, V.; Schellart, A.; Moreno-Rodenas, A.; Muthusamy, M.; Langeveld, J.; ... and Breuer, L. (2019). Recent insights on uncertainties present in integrated catchment water quality modelling. Water research, 150: 368-379.

USEPA (2004). Risk assessment guidance for superfund volume I: human health evaluation manual (part E, supplemental guidance for dermal risk assessment) final. EPA/540/R/99/005 OSWER 9285.7-02EP PB99-963312 July 2004, Office of Superfund Remediation and Technology Innovation.

USEPA (2006). Resources for Information on Risk-Based Concentration Table. Available at http://www.epa.gov/reg3hwmd/risk/human/rbc/rbc1006.pdf.

USEPA (2009). Drinking Water Standards and Health Advisories. Office of Water, Washington, DC, USA. EPA 822-R-09-011.

Weber, P.; Behr, E. R.; Knorr, C. D. L.; Vendruscolo, D. S.; Flores, E. M.; Dressler, V. L. and Baldisserotto, B. (2013). Metals in the water, sediment, and tissues of two fish species from different trophic levels in a subtropical Brazilian river. Microchemical Journal, 106: 61-66.

Weiner, E. R. (2000). Applications in Environmental Chemistry - A Practical Guide for Environmental Professionals, CRC Press, LLC.

WHO (2006). Guidelines for Drinking Water Quality, third ed. World health Organization, Geneva.

Wongsasuluk, P.; Chotpantarat, S.; Siriwong, W. and Robson, M. (2014). Heavy metal contamination and human health risk assessment in drinking water from shallow groundwater wells in an agricultural area in Ubon Ratchathani province, Thailand. Environmental geochemistry and health, 36(1): 169-182.

Wu, B.; Zhao, D. Y.; Jia, H. Y.; Zhang, Y.; Zhang, X. X. and Cheng, S. P. (2009). Preliminary risk assessment of trace metal pollution in surface water from Yangtze River in Nanjing Section, China. Bulletin of environmental contamination and toxicology, 82(4): 405-409.

Yidana, S. M. and Yidana, A. (2010). Assessing water quality using water quality index and multivariate analysis. Environmental Earth Sciences, 59(7): 1461-1473. 
Yin, K.; Wang, Q.; Lv, M. and Chen, L. (2019). Microorganism remediation strategies towards heavy metals. Chemical Engineering Journal, 360: 1553-1563.

Yung, Y. K.; Wong, C. K.; Broom, M. J.; Ogden, J. A.; Chan, S. C. M. and Leung, Y. (1997). Long-term changes in hydrography, nutrient and phytoplankton in Tolo Harbour, Hong Kong. Hydrobiologia, 352(1-3): 107-352.

Zaghloul, F. A. and Hussein, N. R. (2000). Impact of pollution on phytoplankton community structure in Lake Edku, Egypt. Bull. NIOF, 26: 297-318.

Zang, C.; Huang, S.; Wu, M.; Du, S.; Scholz, M.; Gao, F.; ... and Dong, Y. (2011). Comparison of relationships between $\mathrm{pH}$, dissolved oxygen and chlorophyll a for aquaculture and non-aquaculture waters. Water, Air, \& Soil Pollution, 219(1-4): 157-174.

Zhou, Q. Y. and Gao, T. Y. (2000). Environmental engineering microbiology. Beijing: Higher Education.

Zhou, W. H.; Yuan, X. C.; Huo, W. Y. and Yin, K. D. (2004). Distribution of chlorophyll a and primary productivity in the adjacent sea area of Changjiang River Estuary. Acta Oceanologica Sinica, 26(3): 143-150. 